\title{
A novel mutation in the TG gene (G2322S) causing congenital hypothyroidism in a Sudanese family: a case report
}

\author{
Y. Watanabe ${ }^{1}$, E. Sharwood ${ }^{2,3}$, B. Goodwinn 2,4 , M. K. Creech ${ }^{1}$, H. Y. Hassan ${ }^{5}$, M. G. Netea ${ }^{6}$, M. Jaeger ${ }^{6}$, A. Dumitrescu ${ }^{7}$, \\ S. Refetoff ${ }^{8}$, T. Huynh ${ }^{2,3,9}$ and R. E. Weiss ${ }^{1 *}$ (D)
}

\begin{abstract}
Background: Congenital hypothyroidism (CH) has an incidence of approximately 1:3000, but only 15\% have mutations in the thyroid hormone synthesis pathways. Genetic analysis allows for the precise diagnosis.

Case presentation: A 3-week old girl presented with a large goiter, serum TSH > $100 \mathrm{mlU} / \mathrm{L}$ (reference range: 0.7-5.9 $\mathrm{mlU} / \mathrm{L}$ ); free $\mathrm{T}_{4}<3.2 \mathrm{pmol} / \mathrm{L}$ (reference range: $8.7-16 \mathrm{pmol} / \mathrm{L}$ ); thyroglobulin (TG) $101 \mu \mathrm{g} / \mathrm{L}$. Thyroid Tc-99 m scan showed increased radiotracer uptake. One brother had $\mathrm{CH}$ and both affected siblings have been clinically and biochemically euthyroid on levothyroxine replacement. Another sibling had normal thyroid function. Both Sudanese parents reported non-consanguinity. Peripheral blood DNA from the proposita was subjected to whole exome sequencing (WES). WES identified a novel homozygous missense mutation of the TG gene: c.7021G > A, p.Gly2322Ser, which was subsequently confirmed by Sanger sequencing and present in one allele of both parents. DNA samples from 354 alleles in four Sudanese ethnic groups (Nilotes, Darfurians, Nuba, and Halfawien) failed to demonstrate the presence of the mutant allele. Haplotyping showed a 1.71 centiMorgans stretch of homozygosity in the TG locus suggesting that this mutation occurred identical by descent and the possibility of common ancestry of the parents. The mutation is located in the cholinesterase-like (ChEL) domain of TG.

Conclusions: A novel rare missense mutation in the TG gene was identified. The ChEL domain is critical for protein folding and patients with $\mathrm{CH}$ due to misfolded TG may present without low serum TG despite the TG gene mutations.
\end{abstract}

Keywords: Congenital hypothyroidism, Goiter, Novel mutations, Thyroglobulin, TG

\section{Background}

Congenital hypothyroidism $(\mathrm{CH})$ has a worldwide incidence of 1:1500 to 1:4000 depending on the TSH cut-off value used in neonatal screening (NS) $[1,2]$. Mutations in multiple genes have been shown to cause $\mathrm{CH}$ and are grouped into several categories depending on the presence or absence of goiter, level of serum thyroglobulin (TG), and other clinical characteristics [3]. TG is synthesized by the thyroid gland and its primary functions include iodide storage and thyroid hormonogenesis. Thyroxine $\left(\mathrm{T}_{4}\right)$, the predominant form of thyroid hormone $(\mathrm{TH})$, is produced by iodination of select

\footnotetext{
* Correspondence: rweiss@med.miami.edu

${ }^{1}$ Department of Medicine, University of Miami Miller School of Medicine,

1120 NW 14th St., Room 310F, Miami, FL 33136, USA

Full list of author information is available at the end of the article
}

tyrosine residues and coupling pairs of doubly iodinated tyrosines within TG molecules. TG is essential for TH synthesis and homozygous or compound heterozygous mutations of the $T G$ gene can result in permanent $\mathrm{CH}$. To date, 117 TG gene mutations have been reported [4-6]. Most cases with $\mathrm{CH}$ due to $T G$ gene mutations show decreased serum TG levels.

We report an unusual case identified in Australia involving a Sudanese family with familial $\mathrm{CH}$ presenting with goiter and without low serum TG level.

\section{Case presentation Clinical report}

The CARE guidelines were followed in this case. A 3-week old girl born to Sudanese parents in Brisbane, Australia, presented with a large goiter causing upper airway

(c) The Author(s). 2018 Open Access This article is distributed under the terms of the Creative Commons Attribution 4.0 International License (http://creativecommons.org/licenses/by/4.0/), which permits unrestricted use, distribution, and reproduction in any medium, provided you give appropriate credit to the original author(s) and the source, provide a link to the Creative Commons license, and indicate if changes were made. The Creative Commons Public Domain Dedication waiver (http://creativecommons.org/publicdomain/zero/1.0/) applies to the data made available in this article, unless otherwise stated. 
obstruction and producing stridor. Her thyroid stimulating hormone (TSH) on NS was $14 \mathrm{mIU} / \mathrm{L}$ (cut-off range for notification: > $13 \mathrm{mIU} / \mathrm{L}$ ). The result was communicated to the relevant clinicians but, unfortunately, appropriate follow-up had not occurred. At 3 weeks of age when she presented with goiter, serum analysis showed a TSH $>100$ $\mathrm{mIU} / \mathrm{L}$ (reference range: $0.7-5.9 \mathrm{mIU} / \mathrm{L}$ ) with low free $\mathrm{T}_{4}$ of $<3.2 \mathrm{pmol} / \mathrm{L}$ (reference range: $8.7-16 \mathrm{pmol} / \mathrm{L}$ ) and high TG of $101 \mu \mathrm{g} / \mathrm{L}$ (reference range for all age: 1.6-59.9 $\mu \mathrm{g} / \mathrm{L}$ ). The urinary iodine concentration was $0.63 \mu \mathrm{mol} / \mathrm{L}$, suggesting that she had mild iodine deficiency. Thyroid ultrasound and MRI (Fig. 1a) showed both lobes of the thyroid gland to be significantly enlarged. Nuclear scan following injection of $42 \mathrm{MBq}$ Tc-99 $\mathrm{m}$ pertechnetate showed a large goiter with homogeneous markedly increased radiotracer uptake (Fig. 1b). Levothyroxine replacement was started based on the diagnosis of $\mathrm{CH}$ as standard of care.

Her brother was also found to be hypothyroid based on NS, with an elevated TSH of $60 \mathrm{mIU} / \mathrm{L}$. He had been on levothyroxine replacement since that time, with no concerns regarding growth or development. His thyroid ultrasound and nuclear scan at 2 years of age showed a eutopic thyroid gland with increased nuclear tracer uptake of 5.2\% (normal range 1-4\%) following withdrawal of levothyroxine replacement for 5 days. Both siblings had TSH and TH concentrations in the reference ranges while under levothyroxine replacement and with dose adjustment and they have been clinically euthyroid (Fig. 2). The proposita's TG decreased to $2.2 \mu \mathrm{g} / \mathrm{L}$ and the affected brother had low TG of $0.3 \mu \mathrm{g} / \mathrm{L}$. Other members of the family had no symptoms and their thyroid tests were normal (Fig. 2). Subsequent perchlorate discharge studies were performed on the affected brother following withdrawal of levothyroxine replacement for 3 weeks [TSH $180 \mathrm{mIU} / \mathrm{L}$ (reference range: $0.7-4.0 \mathrm{mIU} / \mathrm{L}$ ), $\mathrm{FT}_{4} 4$. $4 \mathrm{pmol} / \mathrm{L}$ (reference range: $7.5-17 \mathrm{pmol} / \mathrm{L}$ ), TG $9.6 \mu \mathrm{g} / \mathrm{L}$ ] and on both parents. The results demonstrated increased uptake of radiotracer in the brother and normal tracer uptake in the parents with no washout of I-123 following perchlorate administration (Fig. 3). This suggests preservation of the organification process [7]. Both maternal and paternal families are non-consanguineous and of Sudanese origin (maternal grandfather; Gogrial and maternal grandmother and paternal grandparents; Aweil East, of South Sudan, respectively). There was no history of thyroid disorders in either family.

\section{Molecular genetics}

Genomic DNA was extracted from peripheral blood leukocytes as previously described [8]. The proposita's DNA was submitted to whole exome sequencing. A panel of 50 genes related to thyroid development, function, serum and cell $\mathrm{TH}$ transport and hormone synthesis was evaluated (Additional file 1: Table S1). This led to the identification of a novel homozygous missense mutation in exon 40 of the TG gene: c.7021G > A, p. Gly2322Ser (numbering excludes 19 amino acid signal peptide). All exonic variants in the TG gene identified in the proposita are summarized in Additional file 2: Table S2. Sanger sequencing confirmed that the affected brother (III2) was homozygous for the same mutation while the parents (II-2 and II-3) and maternal grandmother (I-4) were heterozygous for this mutation, indicating that they were unaffected carriers (Fig. 4a). The other brother (III-1) and the maternal grandfather (I-3) had the wild-type genotype and normal thyroid function tests (Fig. 2 and 4a). This variant was not present in the Genome Aggregation Database (gnomAD) used for analysis. Since the database did not likely include a large number of Sudanese individuals, 354 alleles from 4 Sudanese ethnic groups (Nilotes, Darfurians, Nuba, and Halfawien) [9] were also used for analysis. The TG mutation identified in our family was not present in the 177 Sudanese individuals, suggesting that the variant is rare in the Sudanese as well. Single nucleotide polymorphisms (SNPs) markers with high allele frequencies in the $T G$ locus and markers in the flanking genes were

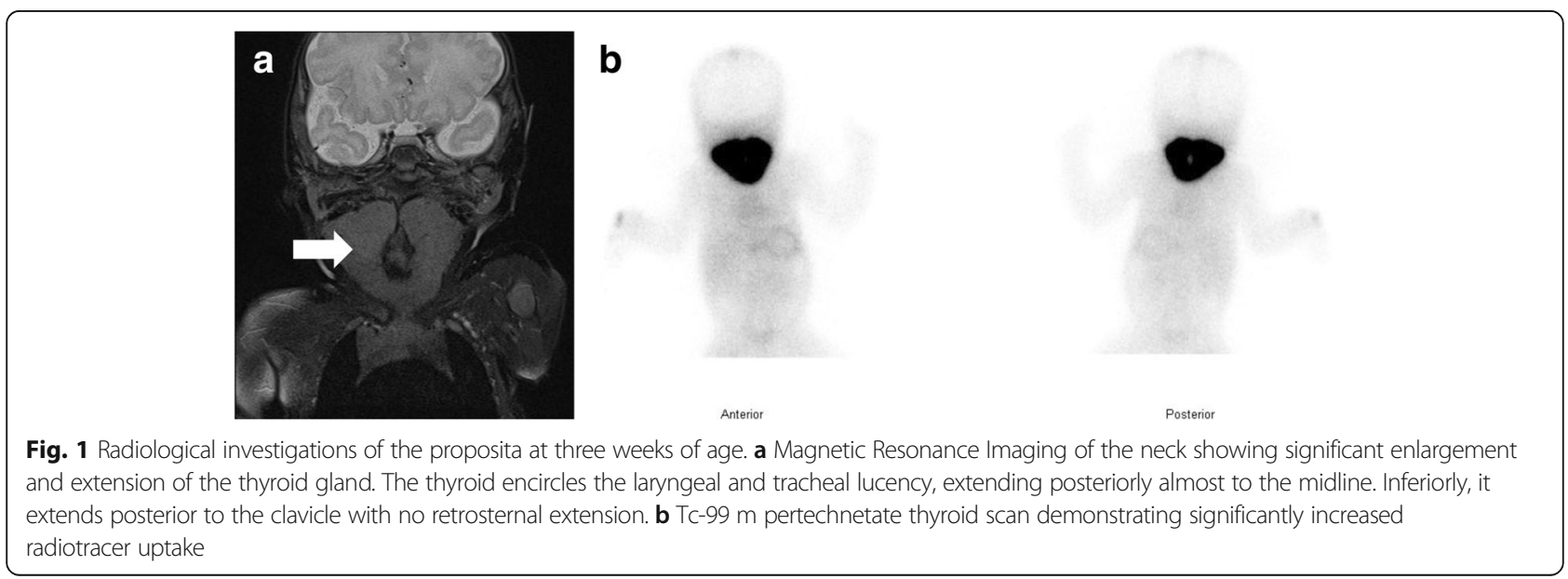




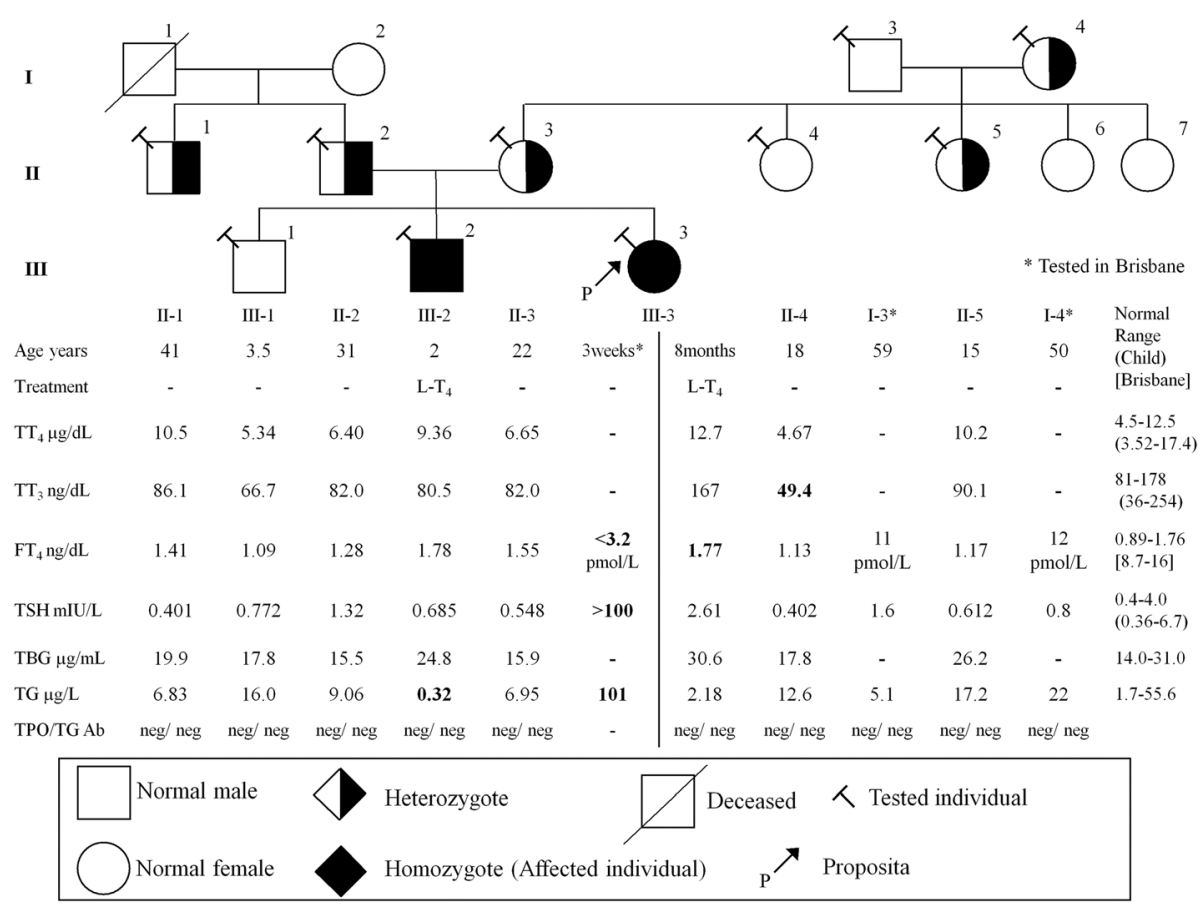

Fig. 2 Pedigree of the family and results of thyroid function tests. Each generation corresponds to a roman number. Arabic numbers above each symbol identify the subjects. Laboratory data are aligned below each symbol. Abnormal values are in bold type. Abbreviations: $L-T_{4} ;$ levothyroxine, $\Pi_{4}$; total thyroxine, $\Pi_{3}$; total triiodothyronine, $\mathrm{FT}_{4}$; free thyroxine, $\mathrm{TSH}$; thyroid-stimulating hormone, TBG; thyroxine binding globulin, $\mathrm{TG}$; thyroglobulin, TPO Ab; anti-TPO antibody, TG Ab; anti-thyroglobulin antibody. The International System of Units: $\Pi_{4} ; \mu \mathrm{g} / \mathrm{dL}=12.87 \mathrm{nmol} / \mathrm{L}, \Pi_{3} ; \mathrm{ng} / \mathrm{dL}=0.0154 \mathrm{nmol} /$ $\mathrm{L}, \mathrm{FT}_{4} ; \mathrm{ng} / \mathrm{dL}=12.87 \mathrm{pmol} / \mathrm{L}, \mathrm{TBG} ; \mu \mathrm{g} / \mathrm{mL}=0.0185 \mu \mathrm{mol} / \mathrm{L}$

genotyped to reconstruct the haplotype for the region (8q24.22) (Fig. 5). The haplotype associated with $\mathrm{CH}$ present in both parents was identical for a stretch of $\sim 1.71$ centiMorgans (cM). The G2322S TG mutation affects a highly conserved amino acid in various species (Fig. 4b) and functional in silico prediction algorithms suggest that this mutation is deleterious (SIFT; 0.001, deleterious and PolyPhen2; 1.0, probably damaging).

\section{Discussion and Conclusions}

A novel homozygous $T G$ gene mutation was identified in two children with $\mathrm{CH}$ and goiter. The unrelated parents are heterozygous for this "rare" mutation and, surprisingly, report non-consanguinity. Haplotype analysis of the SNP makers revealed that the haplotype containing the mutated allele was homozygous over the entire TG locus, spanning $1.71 \mathrm{cM}$ (Fig. 5). This is consistent with the autosomal recessive pattern of inheritance [10]. These results suggest that the mutation occurred identical by descent [11] and that the parents have distant common ancestry [12]. This is likely because Sudan is known for high prevalence of consanguineous marriage [13] and it has been reported that marriage between 1st cousins accounted for more than $40 \%$ marriages [14]. DNA obtained from a Sudanese cohort [9] was analyzed by Sanger sequencing to confirm the frequency of the mutation in the population. However, none of 177 individuals had the mutated allele, indicating the minor allele frequency (MAF) for this variant to be less than 0 . $3 \%$ in the Sudanese population.

The TG protein is composed of three consecutive cysteine (Cys) repeat domains (domains I, II, and III) forming many disulfide bonds. These Cys repeat-domains are followed by the cholinesterase-like (ChEL) domain [4]. Although the TG protein contains 120 Cys, the ChEL domain contains only six Cys. While the mutation in the present case does not directly substitute a Cys residue, it is located in the ChEL domain and is similar to six pathogenic missense mutations previously reported in the domain. Two mutations in the domain (p.A2215D and p.R2223H) occur before the first disulfide bond of ChEL, whereas the remaining four mutations (p. G2300D, p.R2317Q, p.G2355 V, and p.G2356R) fall between the first and second disulfide bonds. The G2322S variant in the present case also resides between the first and second disulfide bonds of the ChEL domain (Fig. 6). We used JPred 4 server for prediction of the secondary structure of the TG [15]. Although the first loop created by the first and second disulfide bonds in the ChEL domain are located away from the $\alpha 7 / 8$ and $\alpha 10$ helices, associated with TG dimerization, or any other $\alpha$ helix motif, the first loop is considered to be important for 


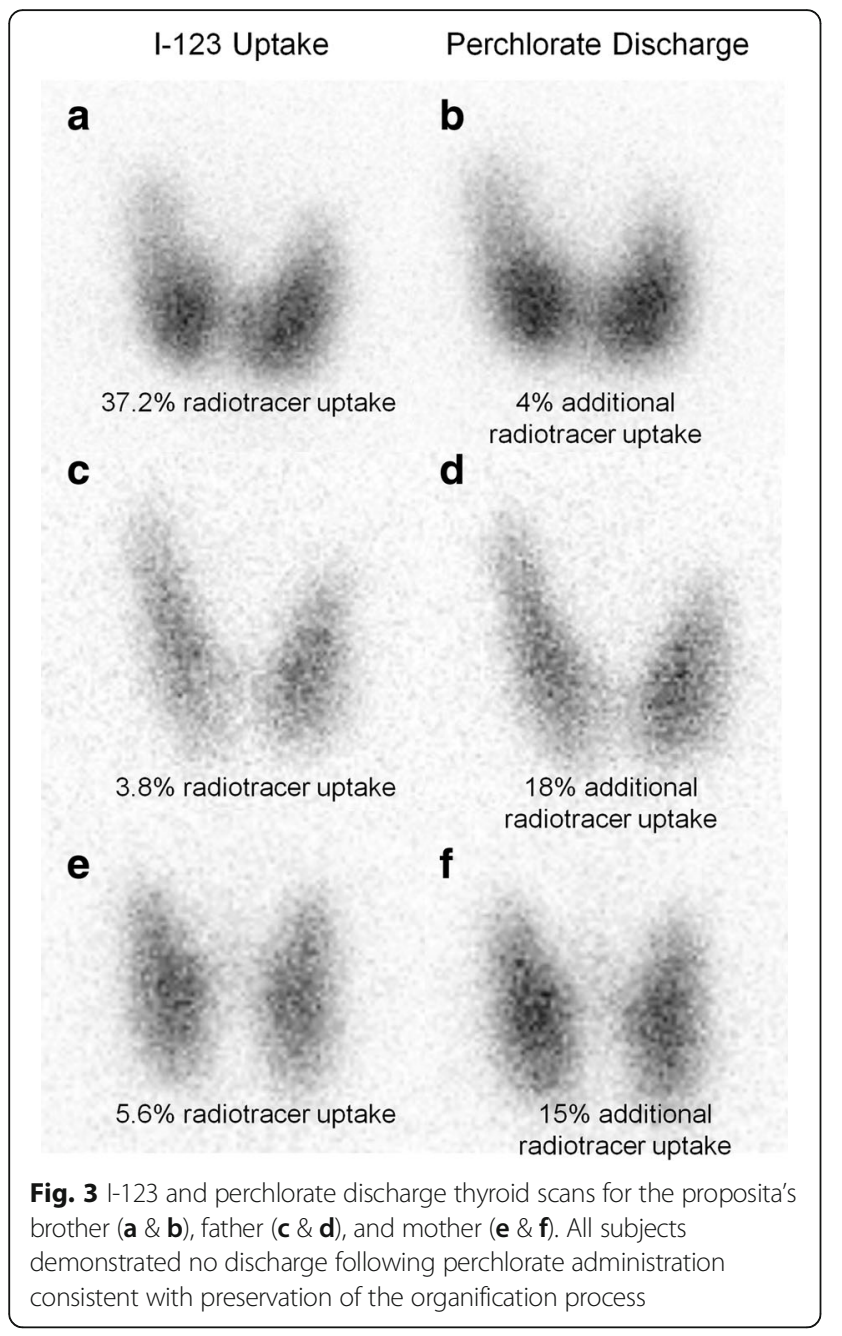

ChEL folding [4]. Interestingly, all pathogenic missense mutations in the ChEL domain are not located in the $\alpha$ helix, however they have been shown to result in $\mathrm{CH}$. Animal studies confirmed that a misfolded TG resulted from similar variants in the ChEL domain. Introduction of p.L2263P in a mouse produced congenital goiter demonstrating that the mutation permitted full-length synthesis of TG but impaired folding necessary for TG homodimerization and transport from the endoplasmic reticulum (ER) $[16,17]$. Another rodent, the $r d w$ rat, harboring the TG p.G2300R mutation exhibited abnormal folding of TG resulting in an extended $\alpha$ helix within the ChEL domain and retention of TG within the ER lumen [18]. The p.G2322S mutation in the present case is located near these mutations, suggesting that TG folding, transport and secretion might be similarly impaired.

Most cases with $\mathrm{CH}$ due to the $T G$ gene mutations show decreased serum TG levels before TH replacement and it is a key factor for the diagnosis of TG defects $[6,19]$. Interestingly, the present case had a TG of $101 \mu \mathrm{g} / \mathrm{L}$ at diagnosis. Reference range of serum TG for infants have not been established. Depending on the platform of analysis, the upper limit of normal for infants between 15 and 180 days was from 43.37 to $147.28 \mu \mathrm{g} / \mathrm{L}$ [20]. Due to lack of a specific TG reference range for infants using our method (IMMULITE $2000^{\circ}$; Siemens, Germany), the TG value of the present case may be high normal, but definitely above values reported in individuals with the $T G$ gene mutations. Moreover, her TG decreased as TSH fell. The affected brother (III-2) had the same mutation in the TG gene, although his TG before levothyroxine replacement

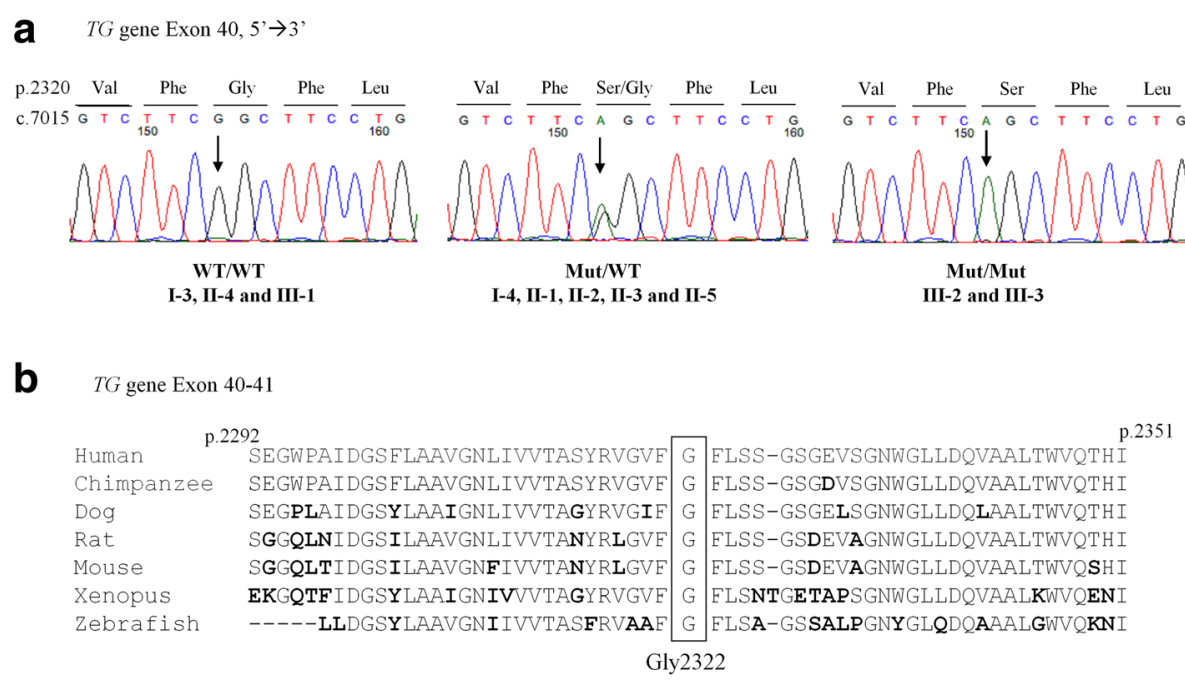

Fig. 4 a Direct sequencing for normal (Wild type/Wild type), heterozygote (Mutant/Wild type) and homozygote (Mutant/Mutant) covering the region of the mutation in exon 40 of the TG gene (c.7021G > A, pGly2322Ser). b Alignment of the TG amino acid sequence encoded by exons 40 and 41 containing the mutant Gly2322 in various species including mammals, amphibian and fish. Amino acid differences are in bold type. Abbreviations: WT; Wild type, Mut; Mutant 


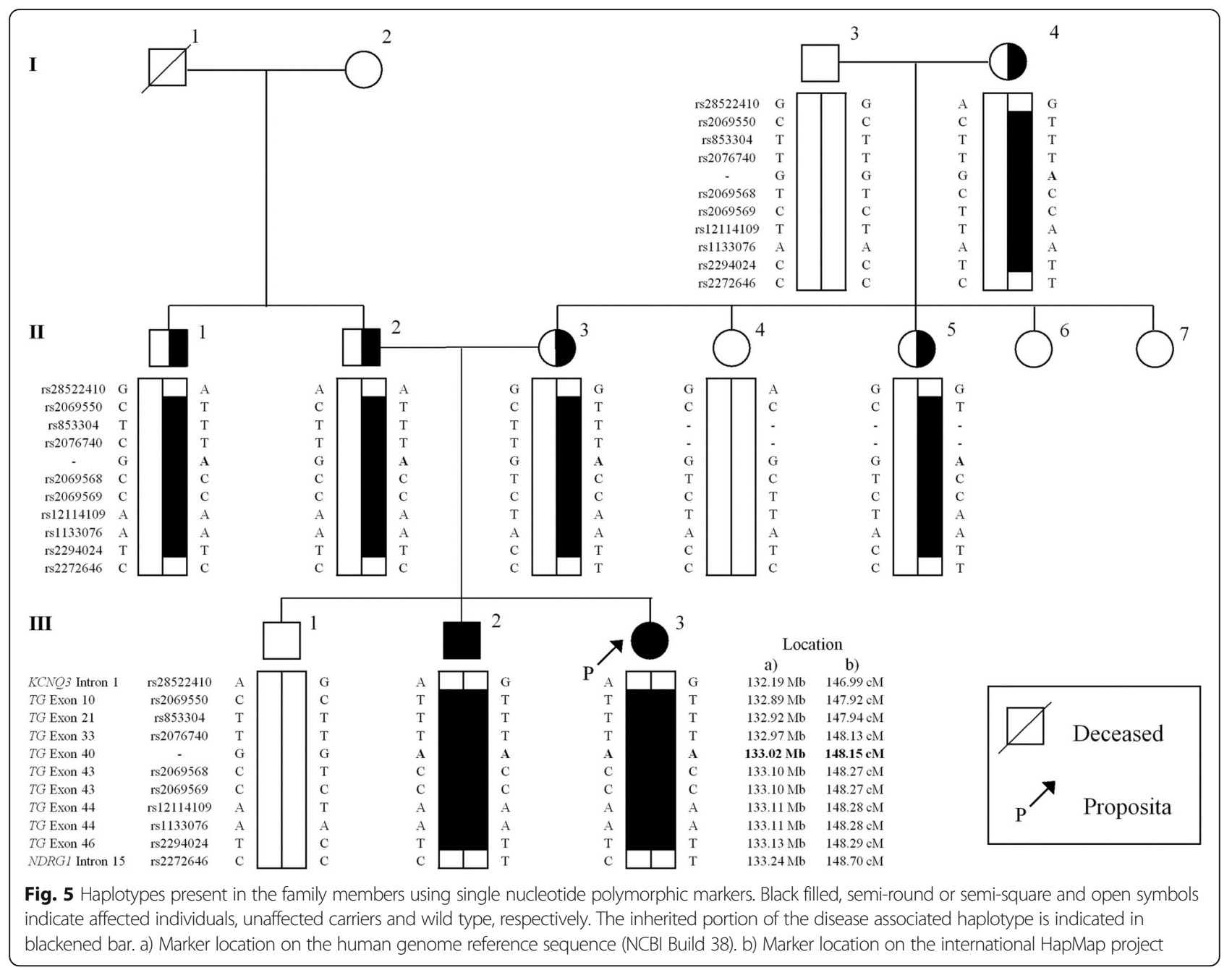

therapy was unknown. Among 61 cases in which serum TG values without $\mathrm{TH}$ replacement were reported, only three cases, beside the present case, showed increased TG (Table 1) [21-23]. The TG mutations p.C1977S and p. A2215D have been reported in multiple cases, and levels of TG in the affected, not included in the list, were normal or low. As with the p.G2322S or p.A2215D in the ChEL domain, the p.C1977S located in the Cys repeat domain III was also associated with misfolding [21, 24]. In general, unfolded protein is blocked from being transported within a cell and then refolded or degraded by chaperone proteins through an intracellular signaling pathway called unfolded protein response (UPR) [24]. Interestingly, absence of the chaperone protein activation was observed in the $\mathrm{p}$. C1977S case with hyperthyroglobulinemia [24]. Thus, incomplete UPR may be associated with secretion of some mutated TG without retention in the ER resulting in higher serum TG. The initial serum TG level of the present case was $101 \mu \mathrm{g} / \mathrm{L}$. In contrast, $\mathrm{CH}$ due to TPO deficiency, in 63 published cases in whom the $T G$ gene was normal had on the average serum TG of more than $1000 \mu \mathrm{g} / \mathrm{L}$ before TH replacement [25-27]. Therefore the TG mutation in the present case resulted in a lesser serum TG level than that observed in $\mathrm{CH}$ due to TPO mutations but higher than that of patients with TG gene mutations in the majority of whom serum TG is undetectable or less than $5 \mu \mathrm{g} / \mathrm{L}$ [19]. The higher level of serum TG in the present case suggests reduced secretion or rapid degradation of a misfolded molecule. As mentioned above, several other cases of TG gene mutations manifesting serum TG levels above $5 \mu \mathrm{g} / \mathrm{L}$ have been reported [21-23].

The affected sibling of the proposita homozygous for the TG mutation had an elevated TSH on NS whereas the proposita (also homozygous for the same mutation) did not. "Delayed TSH rise" has been reported in pre-term and low-birth weight newborns and also some cases with thyroid dyshormonogenesis [28-30]. Incomplete development of hypothalamic-pituitary axis or acute iodine overload is possible cause of the phenomenon. However, the precise pathophysiological mechanisms are still unclear. 


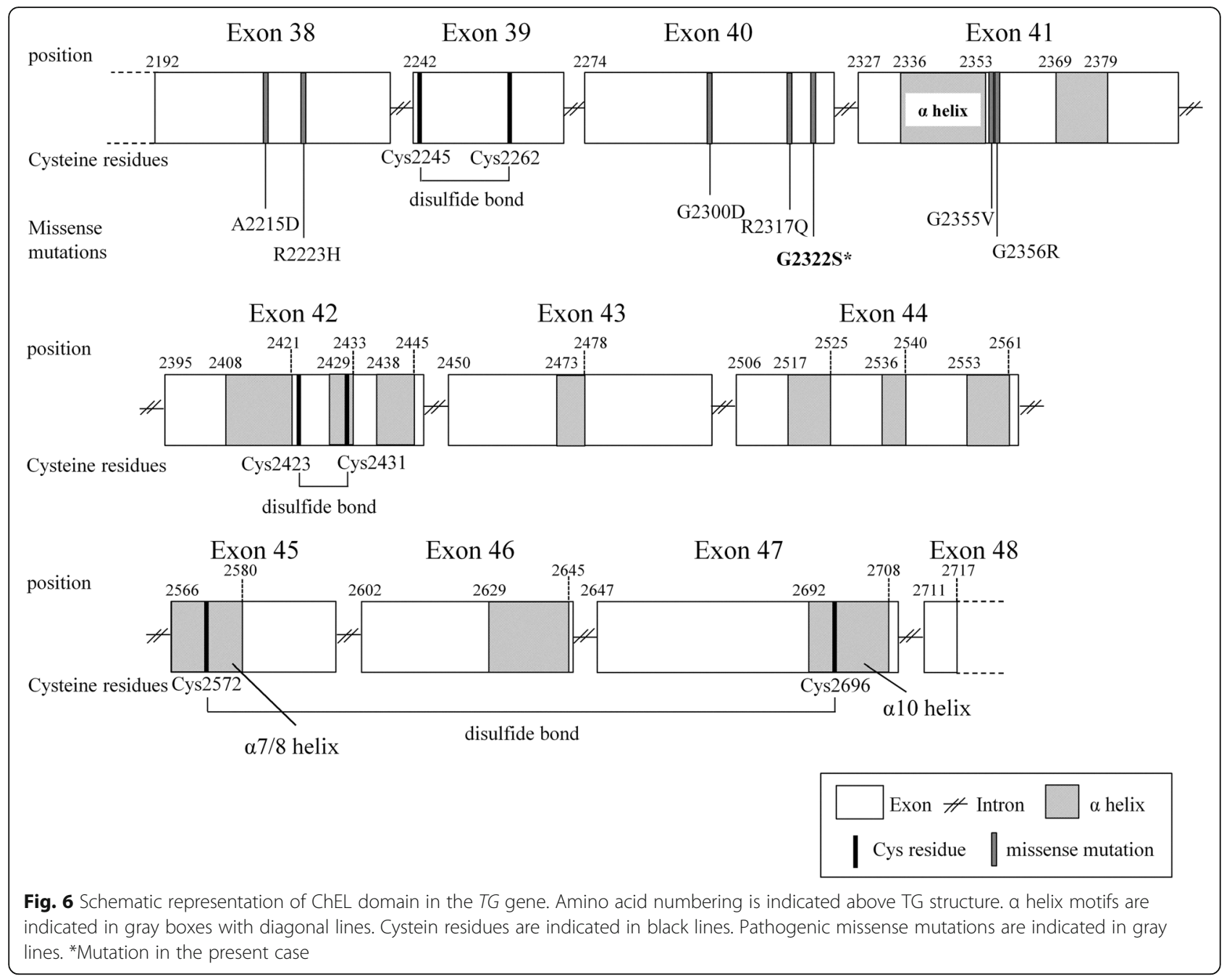

Table 1 Clinical characteristics of the $\mathrm{CH}$ cases due to the TG gene mutations with detectable TG levels

\begin{tabular}{|c|c|c|c|c|c|c|c|c|c|c|c|}
\hline \multicolumn{4}{|c|}{ Position } & \multirow{2}{*}{$\begin{array}{l}\text { Age } \\
\text { Gender }\end{array}$} & \multirow{2}{*}{ Goiter } & \multirow{2}{*}{$\begin{array}{l}\text { TSH (m/U/L) } \\
\text { [normal] }\end{array}$} & \multirow{2}{*}{$\begin{array}{l}\Pi_{4}(\mu \mathrm{g} / \mathrm{dL}) \\
\text { [normal] }\end{array}$} & \multirow{2}{*}{$\begin{array}{l}\mathrm{FT}_{4} \\
(\mathrm{pmol} / \mathrm{L}) \\
{[\text { normal] }}\end{array}$} & \multirow{2}{*}{$\begin{array}{l}\text { TG }(\mu \mathrm{g} / \mathrm{L}) \\
\text { [normal] }\end{array}$} & \multirow[t]{2}{*}{ Antibodies } & \multirow[t]{2}{*}{ References } \\
\hline Exon & Nucleotide & $\begin{array}{l}\text { Amino } \\
\text { Acid }\end{array}$ & TG domain & & & & & & & & \\
\hline 33 & c. 5985 T > A & p.C1977S & Repeat domain III & $\begin{array}{l}\text { adult } \\
\text { F }\end{array}$ & + & $1.7[0.1-4.0]$ & N/A & 9.8 [8-28] & $181[15-50]$ & negative & [21] \\
\hline 33 & c. 5985 T > A & p.C1977s & Repeat domain III & $\begin{array}{l}\text { adult } \\
\text { F }\end{array}$ & + & $1.2[0.1-4.0]$ & N/A & 9.1 [8-28] & 117 [15-50] & negative & [21] \\
\hline 38 & c. $6701 C>A$ & p.A2215D & ChEL & $\begin{array}{l}34 \text { yrs. } \\
M\end{array}$ & + & $4[0.5-4.5]$ & $6[4-12]$ & N/A & 29.2 [1.5-15] & N/A & {$[22,23]$} \\
\hline 40 & c. $7021 \mathrm{G}>\mathrm{A}$ & p.G2322S & ChEL & $\begin{array}{l}3 \text { wks } \\
F\end{array}$ & + & $>100[0.7-5.9]$ & $<3.2$ [8.7-16] & N/A & $101[\mathrm{~N} / \mathrm{A}]$ & negative & $\begin{array}{l}\text { III-3, this } \\
\text { report }\end{array}$ \\
\hline
\end{tabular}

All patients were without $\mathrm{TH}$ replacement at the thyroid function tests

Abbreviations: $T G$ thyroglobulin, $T S H$ thyroid-stimulating hormone, $T_{4}$ total thyroxine, $F T_{4}$ free thyroxine, $N / A$ not available, $L-T_{4}$; levothyroxine, $C h E L$ cholinesterase-like, $F$ Female, $M$ Male, yrs years, wks weeks

The International System of Units: $\Pi_{4} ; \mu \mathrm{g} / \mathrm{dL}=12.87 \mathrm{nmol} / \mathrm{L}$ 
The delayed TSH rise in the proposita may be due to an unknown genetic cause or an environmental factor such as iodine exposure.

In conclusion, a novel homozygous mutation in the $T G$ gene was identified. The mutation was not found in four Sudanese groups of different ethnic origin $(n=177)$. The mutation is located in the ChEL domain of the TG which is essential for protein folding. Patients with $\mathrm{CH}$ due to misfolded TG may present without low serum TG.

\section{Additional files}

Additional file 1: Table S1. Genes related to thyroid disorder. 50 genes related to thyroid development, function, serum and cell TH transport and hormone synthesis. (XLSX $30 \mathrm{~kb}$ )

Additional file 2: Table S2. Exonic variants in the TG gene identified in the proposita by whole exome sequencing. All exonic variants in the $T G$ gene identified in the proposita. (XLSX $41 \mathrm{~kb}$ )

\section{Abbreviations \\ CH: Congenital hypothyroidism; ChEL: Cholinesterase-like; cM: CentiMorgans; Cys: Cysteine; ER: Endoplasmic reticulum; gnomAD: Genome Aggregation Database; L-T: Levothyroxine; MAF: Minor allele frequency; NS: Neonatal screening; SNP: Single nucleotide polymorphism; $\mathrm{T}_{3}$ : Triiodothyronine; $\mathrm{T}_{4}$ : Thyroxine; TG: Thyroglobulin; TH: Thyroid hormone; TSH: Thyroid stimulating hormone; UPR: Unfolded protein response}

\section{Funding}

This research was supported by funds from the Esformes Thyroid Research Fund and National Institutes of Health grant DK15070 to SR and MD010722 to RW.

\section{Availability of data and materials}

The datasets used and analyzed during the current study, such as the raw data from WES sequencing and Sanger sequencing files, are available from the corresponding author on reasonable request.

Web Resources

Genome Aggregation Database (gnomAD): http://

gnomad.broadinstitute.org/

SIFT: http://sift.jcvi.org/

PolyPhen-2: http://genetics.bwh.harvard.edu/pph2/

Jpred 4: http://www.compbio.dundee.ac.uk/jpred/

\section{Authors' contributions}

ES, BG and TH acquired the clinical data. $\mathrm{HH}, \mathrm{MN}$ and $\mathrm{MJ}$ obtained the DNA samples of the Sudanese groups. YW and MC performed the molecular genetic studies and analyzed the data. YW, AD, SR and RW interpreted the data. YW wrote the initial draft of the manuscript which was edited by all authors. All authors read and approved the final manuscript.

\section{Ethics approval and consent to participate}

Molecular genetic study which was performed in Miami has been approved by The Human Subject Research Office of The University of Miami (IRB number: 20140632). Written informed consent for participating in the study has been obtained from all study participants and in the case of subjects under the age of 18 assent was obtained from the child and consent from their parents.

\section{Consent for publication}

Written informed consent for publishing all data of the study, such as medical data, images and genetic results has been obtained from all study participants or in the case of subjects under the age of 18 assent was obtained from the child and consent from their parent.

\section{Competing interests}

The Authors declare that they have no competing interests.

\section{Publisher's Note}

Springer Nature remains neutral with regard to jurisdictional claims in published maps and institutional affiliations.

\section{Author details}

'Department of Medicine, University of Miami Miller School of Medicine, 1120 NW 14th St., Room 310F, Miami, FL 33136, USA. ²Department of Endocrinology and Diabetes, Lady Cilento Children's Hospital, Brisbane, QLD, Australia. ${ }^{3}$ Faculty of Medicine, The University of Queensland, Brisbane, QLD, Australia. ${ }^{4}$ Medical Imaging and Nuclear Medicine, Lady Cilento Children's Hospital, Brisbane, QLD, Australia. ${ }^{5}$ Banoon ART \& Cytogenetics Centre, Bahrain Defence Force Hospital, West Riffa, Kingdom of Bahrain. ${ }^{6}$ Department of Internal Medicine, Radboud University Medical Cente, Nijmegen, The Netherlands. ${ }^{7}$ Departments of Medicine, The University of Chicago, Chicago, IL, USA. ${ }^{8}$ Departments of Medicine, Pediatrics and Genetics, The University of Chicago, Chicago, IL, USA. ${ }^{9}$ Department of Chemical Pathology, Pathology Queensland, Herston, Brisbane, Queensland, Australia.

Received: 15 September 2017 Accepted: 19 April 2018

Published online: 02 May 2018

\section{References}

1. Saleh DS, Lawrence S, Geraghty MT, Gallego PH, McAssey K, Wherrett DK, et al. Prediction of congenital hypothyroidism based on initial screening thyroid-stimulating-hormone. BMC Pediatr. 2016;16:24.

2. Rastogi MV, LaFranchi SH. Congenital hypothyroidism. Orphanet J Rare Dis. 2010;5:17

3. Hannoush ZC, Weiss RE. Defects of thyroid hormone synthesis and action. Endocrinol Metab Clin N Am. 2017;46:375-88.

4. Di Jeso B, Arvan P. Thyroglobulin from molecular and cellular biology to clinical endocrinology. Endocr Rev. 2016;37:2-36.

5. Targovnik HM, Esperante SA, Rivolta CM. Genetics and phenomics of hypothyroidism and goiter due to thyroglobulin mutations. Mol Cell Endocrinol. 2010;322:44-55.

6. Targovnik HM, Citterio CE, Rivolta CM. lodide handling disorders (NIS, TPO, TG, IYD). Best Pract Res Clin Endocrinol Metab. 2017;31:195-212.

7. Grasberger H, Refetoff S. Genetic causes of congenital hypothyroidism due to dyshormonogenesis. Curr Opin Pediatr. 2011;23:421-8.

8. Waltz MR, Pullman TN, Takeda K, Sobieszczyk P, Refetoff S. Molecular basis for the properties of the thyroxine-binding globulin-slow variant in American blacks. J Endocrinol Investig. 1990;13:343-9.

9. Dobon B, Hassan HY, Laayouni H, Luisi P, Ricano-Ponce I, Zhernakova A, et al. The genetics of east African populations: a Nilo-Saharan component in the African genetic landscape. Sci Rep. 2015;5:9996.

10. Lander ES, Botstein D. Homozygosity mapping: a way to map human recessive traits with the DNA of inbred children. Science. 1987;236:1567-70.

11. Thompson EA. Identity by descent: variation in meiosis, across genomes, and in populations. Genetics. 2013;194:301-26.

12. Barkardottir RB, Sarantaus L, Arason A, Vehmanen P, Bendahl PO, Kainu T, et al. Haplotype analysis in Icelandic and Finnish BRCA2 999del5 breast cancer families. Eur J Hum Genet. 2001;9:773-9.

13. Mukhtar $\mathrm{N}$, Elshibli EM, Abdelmonein $\mathrm{H}$, Abdullah MA, Elmula IF. Demographic and Clinical aspects of congenital hypothyroidism (Dyshormonogenesis) in Sudan. Sudan. J Med Sci. 2015;10:109-16.

14. Ahmed AH. Consanguinity and schizophrenia in Sudan. Br J Psychiatry. 1979;134(6):635.

15. Drozdetskiy A, Cole C, Procter J, Barton GJ. JPred4: a protein secondary structure prediction server. Nucleic Acids Res. 2015;43:W389-94.

16. Kim PS, Kwon OY, Arvan P. An endoplasmic reticulum storage disease causing congenital goiter with hypothyroidism. J Cell Biol. 1996;133:517-27.

17. Kim PS, Hossain SA, Park YN, Lee I, Yoo SE, Arvan P. A single amino acid change in the acetylcholinesterase-like domain of thyroglobulin causes congenital goiter with hypothyroidism in the cog/cog mouse: a model of human endoplasmic reticulum storage diseases. Proc Natl Acad Sci U S A. 1998:95:9909-13.

18. Hishinuma A, Furudate S, Oh-Ishi M, Nagakubo N, Namatame T, leiri T. A novel missense mutation (G2320R) in thyroglobulin causes hypothyroidism in rdw rats. Endocrinology. 2000;141:4050-5.

19. Siffo S, Adrover E, Citterio CE, Miras MB, Balbi VA, Chiesa A, et al. Molecular analysis of thyroglobulin mutations found in patients with goiter and 
hypothyroidism. Mol Cell Endocrinol. 2017; https://doi.org/10.1016/j.mce. 2017.12.009.

20. Sobrero G, Munoz L, Bazzara L, Martin S, Silvano L, lorkansky S, et al. Thyroglobulin reference values in a pediatric infant population. Thyroid. 2007;17:1049-54.

21. Hishinuma A, Takamatsu J, Ohyama Y, Yokozawa T, Kanno Y, Kuma K, et al. Two novel cysteine substitutions (C1263R and C1995S) of thyroglobulin cause a defect in intracellular transport of thyroglobulin in patients with congenital goiter and the variant type of adenomatous goiter. J Clin Endocrinol Metab. 1999;84:1438-44.

22. Pardo V, Vono-Toniolo J, Rubio IG, Knobel M, Possato RF, Targovnik HM, et al. The p.A2215D thyroglobulin gene mutation leads to deficient synthesis and secretion of the mutated protein and congenital hypothyroidism with wide phenotype variation. J Clin Endocrinol Metab. 2009;94:2938-44.

23. Vono-Toniolo J, Kopp P. Thyroglobulin gene mutations and other genetic defects associated with congenital hypothyroidism. Arq Bras Endocrinol Metabol. 2004;48:70-82.

24. Baryshev M, Sargsyan E, Wallin G, Lejnieks A, Furudate S, Hishinuma A, et al. Unfolded protein response is involved in the pathology of human congenital hypothyroid goiter and rat non-goitrous congenital hypothyroidism. J Mol Endocrinol. 2004;32:903-20.

25. Avbelj M, Tahirovic H, Debeljak M, Kusekova M, Toromanovic A, Krzisnik C, et al. High prevalence of thyroid peroxidase gene mutations in patients with thyroid dyshormonogenesis. Eur J Endocrinol. 2007;156:511-9.

26. Lee ST, Lee DH, Kim JY, Kwon MJ, Kim JW, Hong YH, et al. Molecular screening of the TSH receptor (TSHR) and thyroid peroxidase (TPO) genes in Korean patients with nonsyndromic congenital hypothyroidism. Clin Endocrinol. 2011;75:715-21.

27. Belforte FS, Miras MB, Olcese MC, Sobrero G, Testa G, Munoz L, et al. Congenital goitrous hypothyroidism: mutation analysis in the thyroid peroxidase gene. Clin Endocrinol. 2012;76:568-76.

28. de Zegher F, Vanderschueren-Lodeweyckx M, Heinrichs C, Van Vliet G, Malvaux P. Thyroid dyshormonogenesis: severe hypothyroidism after normal neonatal thyroid stimulating hormone screening. Acta Paediatr. 1992;81:274-6.

29. Vincent MA, Rodd C, Dussault JH, Van Vliet G. Very low birth weight newborns do not need repeat screening for congenital hypothyroidism. J Pediatr. 2002;140:311-4.

30. Hashemipour M, Hovsepian S, Ansari A, Keikha M, Khalighinejad P, Niknam N. Screening of congenital hypothyroidism in preterm, low birth weight and very low birth weight neonates: a systematic review. Pediatr Neonatol. 2017; https://doi.org/10.1016/j.pedneo.2017.04.006.

Ready to submit your research? Choose BMC and benefit from:

- fast, convenient online submission

- thorough peer review by experienced researchers in your field

- rapid publication on acceptance

- support for research data, including large and complex data types

- gold Open Access which fosters wider collaboration and increased citations

- maximum visibility for your research: over $100 \mathrm{M}$ website views per year

At BMC, research is always in progress.

Learn more biomedcentral.com/submissions 